\title{
Servicescape and Service Quality in Creating Customer Loyalty
}

\author{
Aldina Shiratina ${ }^{1}$, Adnan Rajak ${ }^{2}$, Yanto Ramli ${ }^{3}$, Nuri Putria Nirba Nirwana ${ }^{4}$ \\ ${ }^{1}$ Master of Management Study Program, Mercu Buana University Jakarta \\ ${ }^{2}$ Management Studies Program, Khairun University Ternate \\ ${ }^{3}$ Faculty of Economics and Business, Mercu Buana University Jakarta \\ ${ }^{4}$ Business Administration Study Program, International Women's University \\ Correspondent: aldina.shiratina@mercubuana.ac.id ${ }^{1}$
}

\begin{abstract}
Received : July 27, 2021
Accepted : August 25,2021

Published : October 31, 2021
\end{abstract}

Citation: Shiratina, A., Rajak, A., Ramli, Y., Nirwana, N.P.N. (2021). Servicescape and Service Quality in

Creating Customer Loyalty. Ilomata

International Journal of Management, 2(4), 274-281.

https://doi.org/10.52728/ijim.v2i4.273

\begin{abstract}
The development of cooperatives is currently starting to stagnate. This study aims to reveal this research. This research aims to analyze the effect of Servicescape on customer loyalty, the impact of Servicescape on service quality, the impact of service quality on customer loyalty, and the impact of Servicescape on customer loyalty mediated by service quality. This research uses a quantitative method approach. The unit of analysis in this study was all female members of the Padalarang Partnership Village Cooperative in 2016, totaling 125 people consisting of active and passive female members. The population in this study amounted to 125 people and a set precision or a significance level of 0.05 , so the sample size in this study was 95 members as respondents. This study was analyzed using multiple linear regression for verification analysis. The findings in this study are Servicescape affects service quality, service quality affects the loyalty of female members, and Servicescape affects the loyalty of female members.

Keywords: Cooperative, Gender, Servicescape, Service Quality, Customer Loyalty
\end{abstract}

\section{INTRODUCTION}

The rapidly developing number of cooperatives in Indonesia is likely to increase. Still, the number of cooperatives in the district of West Bandung is stagnant, and even many are no longer active. The number of inactive cooperatives tends to fluctuate in the last three years (BPS, 2020). Cooperatives are another form of implementing a people's economic system. It's believed to be because the cooperative management system can encourage national economic growth. However, at the same time, cooperatives can provide economic equality to the community to be prosperous. The benefits of the cooperative are also felt by the Rural Various Business Partner Cooperative members, most of whom are women. Most rural Various Business Partner Cooperative members are women, and this can be seen from the comparison of the number of male and female members from year to year. Membership is the owner, and service users are very interested in the business run by the cooperative, so members' participation also means developing the cooperative business (Cahyani, 2015). However, if we look at the total number of members, it can be seen that there has been a decrease in the number of members, especially in the last three years of 2016-2019. The decline in the number of cooperatives from 2015 to 2016 
also contributed to the decrease in the number of cooperative members from 37,783,160 people in 2015 to $11,842,415$ people in 2016. This number decreased by $25,940,745$ or $68.66 \%$. Furthermore, from 2016 to 2019, the number of cooperative members began to increase. The number of cooperative members in 2019 was 22,463,738 people. This number is still not able to exceed the number of cooperative members in 2015. When compared between the number of cooperative members in 2019 and 2015, it decreased by 15,319,422 people or 40.55\%.

Sitepu (2018) states that the development of cooperatives is still facing problems both in the institutional field and in the field of the cooperative business itself, while the inhibiting factor in the development of cooperatives is the lack of dedication of the management to the survival of the cooperative. Supervisors, managers do not have a cooperative spirit, so that it must be improved again. It is suspected that the decline was due to the declining loyalty of members towards cooperatives and the lack of government participation in cooperatives. At the same time, the decrease in member loyalty is suspected by the services of a factor that is less comfortable so that the Quality of service is less than optimal.

This customer loyalty is created from the service factor of Othman, Harun, De Almeida, \& Sadq (2020). However, this service is created with the Servicescape, like revealed by Wakefield \& Blodgett (1996) that Servicescape can influence customer behavior such as behavioral intentions toward or avoiding, spending money, and the re-purchase intention; this is a form of customer loyalty. The behavior of approaching or avoiding customers can be interpreted as that they will choose a cooperative servicescape that makes them comfortable in conducting service transactions or vice versa. They will select cooperatives that have specific characteristics that they do not get from other cooperatives. To maintain customer loyalty, Puruwita (2014) reveals that it can be done by consistently maintaining the Quality of services provided to achieve the level of satisfaction expected by customers, which in turn can increase customer loyalty and strive to continue to build better relationships with customers through programs that have added value such as excellent service, etc.

Chun Lee, Barker, \& Kandampully (2003) service system is a very important product for companies engaged in services because it is directly related to efforts to acquire new customers and efforts to retain old customers. The Quality of services provided by service providers to their customers will have an impact on loyalty. According to Lupiyoadi \& Ahmad (2012), the significance of customer loyalty is closely related to the continuity of the company and the strong growth of the company in the future; therefore, retaining existing customers is more important than aggressive strategies such as expanding market size by seeking potential customers.

The purpose of this study is to analyze the effect of Servicescape on customer loyalty, the effect of Servicescape on service quality, the effect of service quality on customer loyalty, and the effect of Servicescape on customer loyalty mediated by service quality. According to Subandi (2009), the notion of cooperatives comes from the English language co-operation, which means joint effort. In other words, it means that all work that is done together can actually be referred to as a cooperative. However, what is meant by a cooperative here is a form of regulation and a specific purpose, a company founded by certain people to carry out certain activities.

According to Buchari (2005), several types of savings in cooperatives are Principal Savings, paid at the time of entry to become a member, may be paid in installments or paid at once, Mandatory Savings, paid continuously on a regular basis, both in amount and the period of payment, Voluntary Deposits, the amount and period of payment are not determined, and may be taken at any time, or may also be arranged in other forms, and the July 12 Cooperative Day Savings and additional special savings.

If we associate with this research that uses gender role as a majority of the members of the cooperatives, namely Nugroho (2011), the word gender in the Indonesian term actually comes 
from the English language, which is "Gender." If you look at the English dictionary, it is not clear that there is a clear distinction between sex and gender. Gender is often equated with sex (male and female sex). After a long time, there has been a process of dividing roles and responsibilities towards men and women that has been going on for years and even centuries; it is difficult to distinguish the meaning of sex (male and female) by gender. According to Firdaus (2012), the reality shows that the Indonesian people fully recognize the importance of the role of women as equal partners to men in development. As a consequence, the realization of the full participation of women, both as actors in activities and as beneficiaries of development results, is not only a matter of human rights and social justice but also concerns economic growth. The purpose of this study is to analyze the effect of Servicescape on customer loyalty, the effect of services cap on service quality, the effect of service quality on customer loyalty, and the effect of Servicescape on customer loyalty mediated by service quality.

The definition of marketing, according to Kotler \& Keller (2016), explains that marketing is an organizational activity and a series of processes for creating, communicating, and providing value to customers, clients, partners, and a wider social circle. Management and marketing management by Kotler and Keller (2016) marketing management is the art and science of choosing target markets and getting, keeping, and growing customers through the creation, delivery, and communicating, superior customer value. Furthermore, regarding services, Wilson, Zeithaml, Bitner, \& Gremler (2012) that services have four main characteristics that greatly affect the design of marketing programs, namely: Intangibility (intangible), Simultaneous production and consumption (produced and consumed simultaneously), Variability or Heterogeneity (changeable), and perishability (not durable).

Lovelock, Wirtz, \& Mussry (2010) defines Servicescape as the style and physical appearance and other experience elements encountered by customers on the service delivery place. The physical condition of the service environment experienced by customers also plays an essential role in shaping the service experience and strengthening (or reducing) customer satisfaction, especially for services at a high level of contact and involving humans in the process. Situmorang, Mulyono, \& Azmi (2017) revealed that the research results show that Servicescape influences customer experience and social location marketing. That is, entrepreneurs or marketers must provide a unique servicescape (color, music, layout, aesthetics, seating, temperature, and cleanliness).

According to the American Society in Kotler \& Keller (2016), "Quality is the totality of the characteristics and characteristics of a product/service in terms of the ability to meet the needs that have been determined. According to Tijptono (2012), the service quality model that is widely used as a reference in service management and marketing research is the SERVQUAL (service quality) model developed by Parasuraman, Zeithaml, and Berry in a series of studies on six service sectors. The SERVQUAL model is widely applied in various companies and industrial contexts.

Kotler \& Keller (2016) loyalty is a deeply held commitment to buy or re-support a preferred product or service in the future despite situational influences and marketing efforts having the potential to cause customers to switch. Customer loyalty, according to Griffin (2007) states that "Customer loyalty is a buying behavior defined by non-random purchases expressed from time to time by several decision-making units."

Musriha, (2012) that Servicescape can influence customer behavioral intentions such as approaching or avoiding behavior, spending money, and intention to make repeat purchases; this is a form of customer loyalty. Servicescape or the physical environment is one of the most important things that need to be considered, especially for service companies. One of the characteristics of a service or service is intangibility or intangible. So, the need for Servicescape 
as physical evidence to give a positive first impression to consumers to create comfort and impact the company's success. Therefore, the creation of an optimal servicescape will encourage the innovation of consumer loyalty. States that the Servicescape is the physical environment or physical facility where these services are produced, delivered, and consumed and emphasizes the impact of the physical environment on a service process taking place.

Alfiani \& Madiawati (2015) quality provides an impetus to customers to forge a strong relationship with the company. Customer satisfaction can create customer loyalty or loyalty to companies that provide satisfactory Quality. Furthermore, Muzammil, Yunus, Darsono, \& Nurdasila (2017) revealed that service quality has a significant and positive effect on customer satisfaction which will later create customer loyalty. According to Tjiptono (2008), service facilities that are neatly arranged, attractive, and aesthetically pleasing will increase the customer's positive attitude towards service. In addition, employee attitudes towards work and work motivation can also increase.

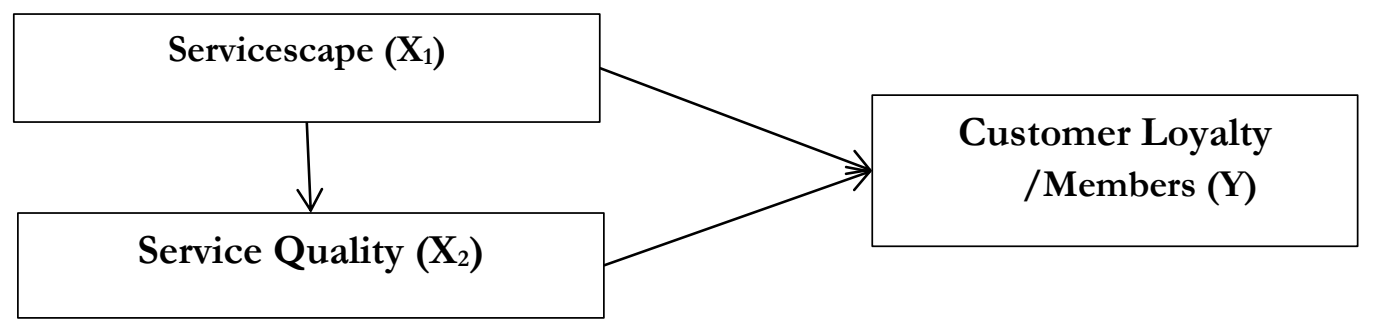

Figure 1. Research Model

\section{METHOD}

The method used in this research is descriptive and verification design with a quantitative approach and survey method. According to Sugiyono (2013), quantitative research methods can be interpreted as research methods based on the philosophy of positivism, used to examine certain populations or samples, sampling techniques are generally carried out randomly, data collection uses research instruments, data analysis is quantitative/statistics to test the established hypothesis. According to Nazir (2013), the survey method is an investigation conducted to obtain facts from existing symptoms and seek factual information, whether about social, economic, or political institutions of a group or an area. The research was conducted at the Cooperative of Various Business Partners in Rural District, Padalarang District.

The population in this study were all female members of the Padalarang Rural Cooperative Aneka Usaha Mitra in 2016, totaling 125 people consisting of active and passive female members. The population in this study amounted to 125 people, and the specified precision or significance level was 0.05 , so the sample size in this study was 95 people. In this study, there is more than one independent variable that will be tested to determine its effect on the dependent variable, then use multiple linear regression. According to Gujarati (2012), regression is a study of the dependence of one variable, namely the dependent variable on one or more other variables or what is referred to as explanatory variables, with the aim of making estimates or predicting the population average or the average value of the variable. Depends on the known values of the explanatory variables.

\section{RESULTS AND DISCUSSION}

The results of the regression analysis in this study were used to examine the effect of Servicescape on the loyalty of female members, presented in table 1 as follows: 
Table 1. First Hypothesis Regression Analysis

\begin{tabular}{ccccc}
\hline Constant & Regression Coefficient & t count & Sig. & Adjusted R $^{2}$ \\
\hline 0.417 & 0.846 & 9,178 & 0.000 & 0.470 \\
\hline
\end{tabular}

Source: Primary Data processed 2020

Based on the table, there are several explanations, including:

a. Regression Equation

From the results of the regression analysis can be seen the following regression equation:

$$
\mathrm{Y}=0.417+0.846 \mathrm{X}
$$

The regression equation shows that the servicescape coefficient $(\mathrm{X})$ is 0.846 , which means that if the servicescape increases by one unit, the loyalty of female members will increase by 0.846 units.

b. Regression significance test with t-test

The results of the t-test for the servicescape variable obtained an at-count value of 9.178 with a significance level of 0.000 because the significance level is less than $0.05(0.000$ $<0.05$ ), and the regression coefficient has a positive value of 0.846 , then the hypothesis which states that "Servicescape has an effect on the loyalty of female members in the Aneka Usaha Mitra Rural Padalarang Cooperative" proven.

c. Coefficient of Determination (Adjusted $\mathrm{R}^{2}$ )

The magnitude of the effect of Servicescape on the loyalty of female members is 0.470 ; this means that the loyalty of female members is influenced by the Servicescape by $47 \%$, while the remaining $53 \%$ is influenced by other factors not included in this study.

The results of regression analysis in this study were used to examine the effect of Servicescape on service quality, presented in table 2 as follows:

Table 2. Second Hypothesis Regression Analysis

\begin{tabular}{ccccc}
\hline Constant & Regression Coefficient & t count & Sig. & Adjusted R \\
\hline 1.085 & 0.636 & 8,595 & 0.000 & 0.437 \\
\hline
\end{tabular}

Source: Primary Data processed 2020

Based on the table, there are several explanations, including:

a. Regression Equation

From the results of the regression analysis can be seen the following regression equation:

$$
\mathrm{M}=1.085+0.636 \mathrm{X}
$$

The regression equation shows that the servicescape coefficient $(X)$ is 0.636 , which means that if the Servicescape increases by one unit, the service quality will increase by 0.636 units.

b. Regression significance test with t-test

The results of the t-test for the servicescape variable obtained an at-count value of 8.595 with a significance level of 0.000 because the significance level is less than $0.05(0.000<0.05)$, and the regression coefficient has a positive value of 0.636 ; then the hypothesis which states that "Servicescape has an effect on the quality of service in the Cooperative of Various Business Partners in Rural Padalarang. " proven.

c. Coefficient of Determination (Adjusted $\mathrm{R}^{2}$ )

The magnitude of the effect of Servicescape on service quality is 0.437 ; this means that service quality is influenced by Servicescape by $43.7 \%$, while the remaining $56.3 \%$ is influenced by other factors not included in this study.

The results of the regression analysis in this study were used to examine the effect of service quality on the loyalty of female members, presented in table 3 as follows:

Table 3. Third Hypothesis Regression Analysis Results 


\begin{tabular}{ccccc}
\hline Constant & Regression Coefficient & t count & Sig. & Adjusted R ${ }^{2}$ \\
\hline-0.306 & 1.076 & 14,781 & 0.000 & 0.698 \\
\hline
\end{tabular}

Source: Primary Data processed 2020

Based on the table, there are several explanations, including:

a. Regression Equation

From the results of the regression analysis can be seen the following regression equation:

$$
\mathrm{Y}=-0.306+1.076 \mathrm{Z}
$$

The regression equation shows that the value of the service quality coefficient $(Z)$ is 1.076, which means that if the service quality increases by one unit, the loyalty of female members will increase by 1.076 units.

b. Regression significance test with t-test

The results of the t-test for the service quality variable obtained an at-count value of 14,781 with a significance level of 0.000 because the significance level is less than $0.05(0.000$ $<0.05$ ), and the regression coefficient has a positive value of 1.076; then the hypothesis which states that "Quality of service affects the loyalty of female members in the Padalarang Rural Mitra Usaha Cooperative. " proven.

c. Coefficient of Determination (Adjusted $\mathrm{R}^{2}$ )

The magnitude of the effect of service quality on the loyalty of female members is 0.698 ; this means that the loyalty of female members is influenced by service quality by $69.8 \%$, while the remaining $30.2 \%$ is influenced by other factors not included in this study.

In this research can be discussed that influence servicescape loyalty customer rated medium it is because customers or members of the cooperative less attention servicescape provided by the cooperative, although sometimes some members who pay attention to Servicescape but not many as revealed by Juliana \& Noval (2020) that the research results show that the ambient dimensions, design dimensions, social dimensions which are dimensions of the Servicescape can have a significant effect on consumer loyalty. The influence of Servicescape on the Quality of the customer can be quite strong. This is because Servicescape is aimed at supporting the Quality of service, as revealed by Ferdinal \& Tjahjawati (2017) that in their research, it shows that there is a positive relationship between Servicescape on the Quality of service. Meanwhile, the Quality of service on customer loyalty is considered to have a strong influence, as revealed by Putri \& Utomo (2017) that service quality has a significant direct effect on customer loyalty.

\section{CONCLUSIONS}

Based on the results and discussion above, it can be seen that customer loyalty, in this case, female members of the cooperative, can be created from the existence of good service quality and an optimal servicescape. The suggestions in this study are intended for further researchers to be able to do more research on the servicescape variable to explore further and for the current cooperative to maximize service to its members, especially female members.

\section{ACKNOWLEDGEMENTS}

In this study, we thank all relevant parties, including international women's universities and cooperatives.

\section{REFERENCES}

Alfiani, W., \& Madiawati, P. N. (2015). Pengaruh Brand Image Dan Service Quality Terhadap 
Loyalitas Pelanggan Pada Pengguna Jasa Paketpos Pt. Pos Indonesia (persero) Kantor Pusat Bandung. EProceedings of Management. https://t.ly/W4zy

Alma, B. (2014). Manajemen Pemasaran dan Pemasaran Jasa (14th ed.). CV. Alfabeta. https://cvalfabeta.com/product/manajemen-pemasaran-dan-pemasaran-jasa/

Cahyani, M. T. (2015). Pengaruh Jumlah Anggota Terhadap Perolehan Sisa Hasil Usaha Melalui Partisipasi Anggota Sebagai Variabel Intervening Pada Koperasi Simpan Pinjam Wisuda Guna Raharja Denpasar Tahun 2012-2014. Jumal Jurusan Pendidikan Ekonomi (JJPE), 5(1). https://doi.org/http://dx.doi.org/10.23887/jjpe.v5i1.6392

Chun Lee, S., Barker, S., \& Kandampully, J. (2003). Technology, Service Quality, and Customer Loyalty in Hotels:Australian Managerial Perspektives. Managing Service Quality., 13(5), 423. https://doi.org/https://doi.org/10.1108/09604520310495886

Ferdinal, E., \& Tjahjawati, S. S. (2017). Pengaruh Servicescape Terhadap Kualitas Pelayanan. Jurnal Riset Bisnis Dan Investasi, 3(1). https://doi.org/https://doi.org/10.35313/jrbi.v3i1.546

Firdaus, E. (2012). Kemitrasejajaran Peran Gender Dalam Wacana Legalitas Indonesia. Jurnal Pendidikan Agama Islam Ta'lim, http://jurnal.upi.edu/199/view/1667/kemitrasejajaran-peran-gender-dalam-wacanalegalitas-indonesia.html

Griffin, J. (2007). Customer Loyalty: Menumbubkan dan Mempertahankan Kesetiaan Pelanggan (Y. Sumiharti, R. Medya, \& W. Kristiaji (eds.)). Erlangga. http:/ /lib.ui.ac.id/detail.jsp?id=137221

Gujarati, D. N. (2012). Dasar-Dasar Ekonometrika (C. Mangunsong (ed.); 5th ed.). Salemba Empat. https://library.ui.ac.id/detail?id=20395756

Juliana, \& Noval, T. (2020). Pengaruh Servicescape terhadap Loyalitas Konsumen Di Restoran Chakra The Breeze Bumi Serpong Damai. Jurnal Ecodemica, 4(1). https://ejournal.bsi.ac.id/ejurnal/index.php/ecodemica/article/view/6150

Kotler, P, \& Keller, K. L. (2016). Marketing Management (15th ed.). Pearson Education, Inc. https://www.pearson.com/us/higher-education/product/Kotler-Marketing-Management15th-Edition/9780133856460.html

Kotler, Philip, \& Keller, L. (2012). Marketing Management (14th ed.). Pearson Education Limited.

Lovelock, C., Wirtz, J., \& Mussry, J. (2012). Pemasaran Jasa Perspektif Indonesia (2nd ed.). Erlangga. https://www.erlangga.co.id/manajemen/7817-pemasaran-jasa-perspektif-indonesia-jilid-1a-2-.html

Lupiyoadi, R., \& Ahmad, H. (2012). Manajemen Pemasaran Jasa (1st ed.). Salemba Empat. https://penerbitsalemba.com/buku/02-0311-manajemen-pemasaran-jasa-berbasiskompetensi-e3-

Musriha, M. (2018). Pengaruh Servicescape dan Kualitas Komunikasi Karyawan Terhadap Loyalitas Melalui Kepuasan Nasabah Bank Mandiri di Surabaya. EKUITAS (Jurnal Ekonomi Dan Keuangan), 15(2), 247-268. https://doi.org/10.24034/j25485024.y2011.v15.i2.273

Muzammil, A., Yunus, M., Darsono, \& Nurdasila. (2017). Pengaruh Kualitas Pelayanan Dan Citra Perusahaan Terhadap Loyalitas Pelanggan Indihome Pt. Telkom Indonesia Di Banda Aceh Dengan Kepuasan Dan Kepercayaan Pelanggan Sebagai Variabel Mediasi. Jurnal Manajemen Dan Inovasi, $\quad 8(3), \quad$ 104-133. https://doi.org/https://doi.org/10.24815/jmi.v8i3.9342

Nazir, M. (2013). Metodologi Penelitian (R. Sikumbang (ed.); 1st ed.). Ghalia Indonesia. https:/ /opac.perpusnas.go.id/DetailOpac.aspx?id=711887 
Nugroho, R. (2011). Gender dan Strategi Pengarus-utamanya di Indonesia. Pustaka Pelajar. https://pustakapelajar.co.id/buku/gender-dan-strategi-pengarus-utamaannya-di-indonesia/

Othman, B. A., Harun, A., De Almeida, N. M., \& Sadq, Z. M. (2021). The effects on customer satisfaction and customer loyalty by integrating marketing communication and after sale service into the traditional marketing mix model of Umrah travel services in Malaysia. Journal of Islamic Marketing, 12(2), 363-388. https://doi.org/10.1108/JIMA-09-2019-0198

Puruwita, D. (2014). The Influence Cellular Provider Service Quality Towards Customer Loyalty Indosat in Jakarta. Jurnal Pendidikan Ekonomi Dan Bisnis JPEB), 2(2), 53. https://doi.org/10.21009/JPEB.002.2.4

Putri, Y. L., \& Utomo, H. (2017). Pengaruh Kualitas Pelayanan Terhadap Loyalitas Pelanggan Dengan Kepuasan Sebagai Variabel Intervening (Studi Persepsi Pada Pelanggan Dian Comp Ambarawa. Among Makarti, 10(1). https://doi.org/10.52353/ama.v10i1.147

Sitepu, C. F., \& Hasyim, H. (2018). Perkembangan Ekonomi Koperasi di Indonesia. NIAGAWAN, 7(2). https://doi.org/10.24114/niaga.v7i2.10751

Situmorang, S. H., Mulyono, H., \& Azmi, A. (2018). Effect Of Servicescape And Customer Experience On Social Location Marketing (Case Study At Caf, In Medan). Proceedings of the 1st Economics and Business International Conference 2017 (EBIC 2017), 46. https://doi.org/10.2991/ebic-17.2018.86

Subandi. (2009). Ekonomi Koperasi Teori dan Praktik (Riduwan (ed.)). Alfabeta. https://openlibrary.telkomuniversity.ac.id/pustaka/16989/ekonomi-koperasi-teori-danpraktik-.html

Sugiyono. (2019). Metode Penelitian Kuantitatif Kualitatif dan R\&D (I). Alfabeta. https://cvalfabeta.com/product/metode-penelitian-kuantitatif-kualitatif-dan-rd-mpkk/

Tjiptono, F. (2007). Pemasaran Jasa. Bayu Media Publishing. http://library.fis.uny.ac.id/opac/index.php?p=show_detail\&id=2136http:/ /library.fis.uny. ac.id/opac/index.php?p=show_detail\&id $=2136$

Tjiptono, F. (2012). Pemasaran Strategic (2nd ed.). Andi Publisher. https://andipublisher.com/produk-strategi-pemasaran-edisi-4

Wakefield, K. L., \& Blodgett, J. G. (1996). The effect of the servicescape on customers' behavioral intentions in leisure service settings. Journal of Services Marketing, 10(6), 45-61. https://doi.org/10.1108/08876049610148594

Wilson, A., Zeithaml, V. A., Bitner, M. J., \& Gremler, D. D. (2012). Services Marketing: Integrating Customer Focus Across the Firm. (2nd ed.). McGraw-Hill. https://openlibrary.telkomuniversity.ac.id/pustaka/8675/services-marketing-integratingcustomer-focus-across-the-firm.html 